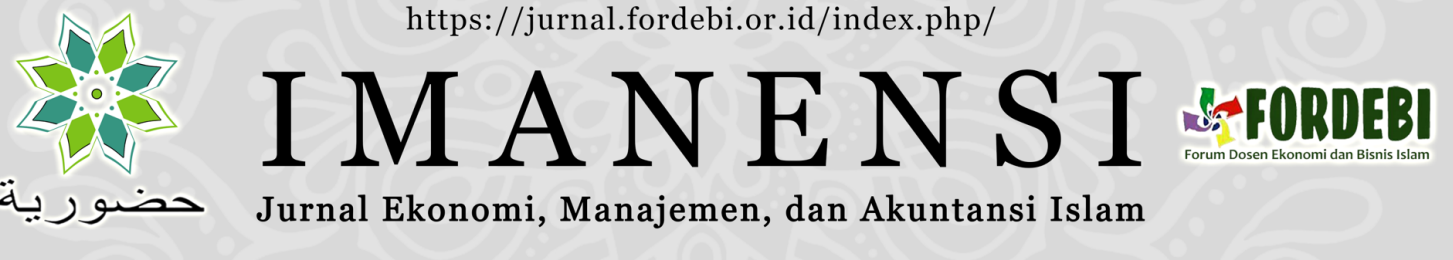

\title{
POVERTY REDUCTION IN ISLAMIC POLITICAL ECONOMY ACCORDING TO ABDURRAHMAN AL-MALIKI'S PERSPECTIVE
}

\author{
Nunung Nurlaelaa,1 \\ a Sekolah Tinggi Ekonomi Islam Hamfara Yogyakarta, Dusun Kenalan, Bantul, Daerah Istimewa \\ Yogyakarta, 55184, Indonesia \\ 1ummunawazim@gmail.com* \\ *Corresponding author
}

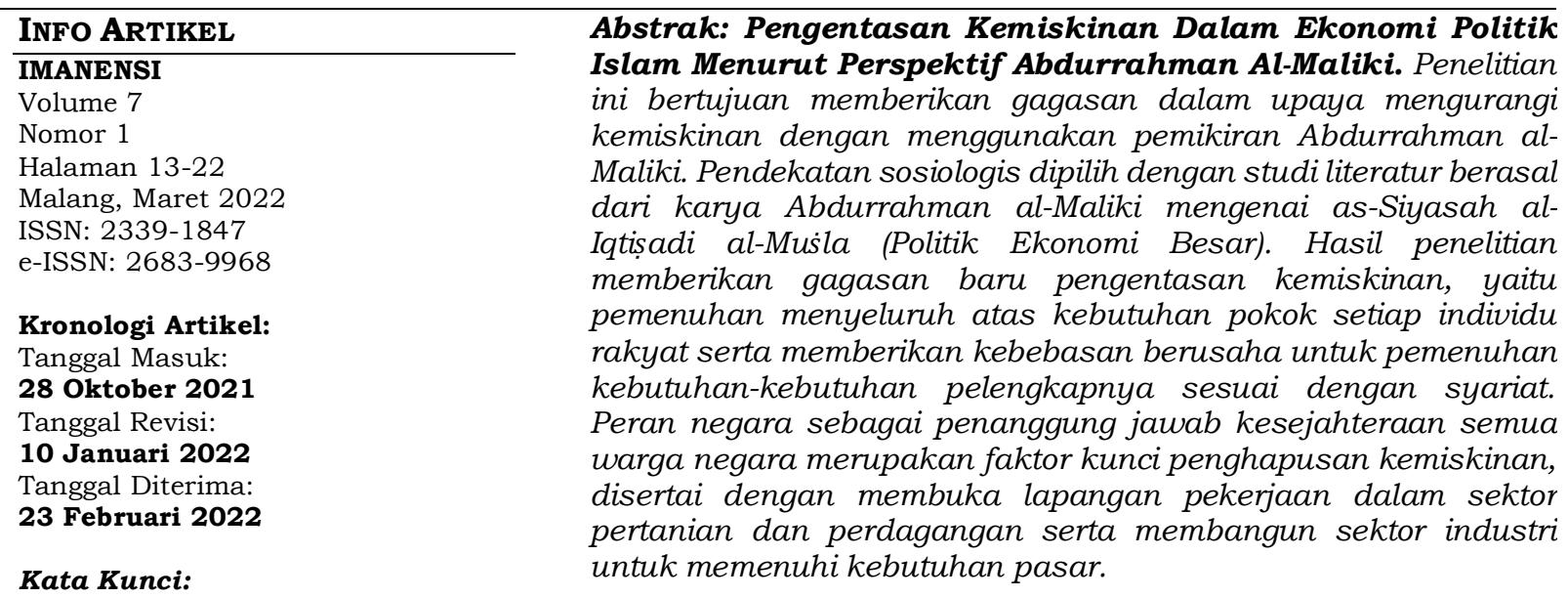

Abdurrahman al-Maliki;

Ekonomi Politik;

Makro Ekonomi;

Pemerintah;

Pengentasan Kemiskinan.

\section{Keywords:}

Abdurrahman al-Maliki;

Government;

Macroeconomics;

Political Economy;

Poverty Alleviation.

\begin{abstract}
Poverty Reduction In Islamic Political Economy According To Abdurrahman Al-Maliki's Perspective. This study aims to provide ideas in an effort to reduce poverty by using the thoughts of Abdurrahman al-Maliki. The sociological approach was chosen by studying literature derived from the work of 'Abdurrahman al-Maliki on as-Siyasah al-Iqtisadi alMusla (Great Economic Politics). The results of the study provide new ideas for poverty alleviation, namely the complete fulfillment of the basic needs of each individual people and provide freedom of business to fulfill complementary needs in accordance with the Shari'a. The role of the state as the person in charge of the welfare of all citizens is a key factor in eradicating poverty, accompanied by creating job opportunities in the agricultural and trade sectors and building the industrial sector to meet market needs.
\end{abstract}

Disitasi sebagai: Nurlaela, N. (2022). Poverty Reduction In Islamic Political Economy According To Abdurrahman Al-Maliki's Perspective. IMANENSI: Jurnal Ekonomi, Manajemen, dan Akuntansi Islam, 7(1), 13-22. https://doi.org/10.34202/imanensi.6.2.2021.13-22.

\section{BACKGROUND}

Poverty remains on the big agenda of all governments in the world, especially in developing countries. Poverty is divided into three categories, namely: (1) very-poor, (2) poor, and (3) near-poor. The first category is an individual who is unable to meet their food as much as 2,100 calories per day. The poor category is an individual who is unable to meet their basic needs, while the near-poor category is a condition of an 
individual who has an income of less than USD 2 per day.

Ikhsan (2010) stated that the MDGs report from the World Bank shows that economic growth in developing countries has succeeded in reducing the poverty rate by 446 million in 1990-2005. This decline is still below the desired target because there are still 918 million poor people in 2015. Part of the reason is the global economic crisis and the economic growth, that not enough to drive poverty reduction. Effective government intervention is needed to assist the improvement process.

The one of basic weaknesses of Indonesia's economy is its tendency to the haves and strong group more than the poor. This tendency that has deteriorated this current economic crisis occurs because of a capital system implemented by Indonesia. So. Indonesia has to develop a people-centered economy, both in its economic system and politics (Mubyarto, 1999). The problem of poverty is indeed complex and multidimensional. Therefore, poverty alleviation efforts must be carried out comprehensively, covering various aspects of people's lives, and implemented in an integrated manner (Papilaya, 2020). Aprianto (2017) describes two strategic political-economic steps for poverty reduction, namely (1) improving infrastructure that causes poverty through political channels and (2) government intervention in order to increase economic growth and optimize economic distribution. Syaiful Ilmi (2017) provides an overview of three poverty alleviation steps, namely: (1) reconstruction of poverty theology, (2) building collective awareness of poverty eradication, and (3) building an individual work ethic. This is the general solution offered by many parties.

The question is, will this solution really be able to eradicate poverty in real terms? Abdurrahman al-Maliki (2001) provides a new idea for poverty alleviation, namely the complete fulfillment of the basic needs of each individual people and providing freedom of business to fulfill complementary needs in a legitimate business field in accordance with the Shari'a. The proposed political economy is not only about increasing the standard of living in a country.

\section{METHOD}

This research is a type of qualitative research with a sociological approach using descriptive analysis methods. Qualitative research departs from problems that are still dim, sometimes even starting from dark conditions, the scope of the discussion is complex and dynamic so that it can develop or even change after the researcher is in the field. Through qualitative research, it is expected to be able to see the phenomenon more broadly and deeply in accordance with what is happening and developing in the social situation under study (Sugiyono, 2017).

The data collection in this study is by documentation, namely taking data from the original source as well as the necessary secondary sources, namely as-Siyasah al-Iqtișadi al-Muśla (Great Economic Politics) by 'Abdurrahman al-Maliki. Data Analysis Method Descriptive analysis is a method that describes the important properties of the data and is presented in the form of a systematic description of description.

\section{RESULT AND DISCUSSION}

\subsection{Poverty and Partial Solutions}

Poverty is a complex and multidimensional development problem. Thus, to overcome poverty, a collective effort needs to solve by involving the government and society in developing and implementing comprehensive, integrated, effective, and sustainable strategies. Need Several efforts to encourage self-reliance and partnership between the community and regional government in elevating urban 
poverty (Sugandi, 2016). Two political-economic strategies can reduce poverty, a political way to optimize infrastructure that caused poverty and government intervention to improve the economy, both production and distribution (Aprianto, 2017). The condition of poverty in Indonesia is not much different from that of other developing countries. Data on poverty in Indonesia from 2011-2017 can be look in table 1. BPS data shows the poverty rate is still high, with an average of 28.23 million people or $11.2 \%$ of the population. It's just that the poverty standard used by BPS in the data is below the world poverty standard, which is USD 2 per capita per day. We assumed that the USD exchange rate against the rupiah IDR 13,000 in 2017, the World Bank version of the poverty standard is IDR 26,000 per capita per day or around IDR 780,000 per capita per month. So the standard poverty line is only about 1 USD per capita.

The condition of the still large number of poor people clearly shows that the government has not succeeded in prospering the people. This means that the development carried out by the government so far has not been able to lift the fate of tens of millions of poor people, even though there have been improvements to the structure and infrastructure in many aspects. A large number of poor people actually shows that there are structural problems in state management. The magnitude of this figure must be related to the state's decision, not just because of the people's laziness in trying. The fact that there are still many people who live below the poverty line on the one hand and that there are enormous natural resources on the other is a paradox in itself. The Indonesian people cannot enjoy their own wealth, even though the Constitution states "Earth and water and the wealth contained therein are controlled by the state and used as much as possible for the prosperity of the people", but in fact, this has not been going well. The current reality is that there are still many people who feel aggrieved or not treated fairly. In fact, every people should have rights in this matter such as basic needs, including the need for clean water, fuel, and other natural resources.

The state as one of the economic actors, also leads to an increase in prosperity as other economic actors, in this case, prosperity and welfare for all its people. The goal of economic development is to achieve a high level of prosperity for all levels of society, and not just for certain groups. This is a basic description of economic development and at the same time a measure of the success of the distribution function of state finances. Prosperity for every economic actor means an increase in value from a certain value point to a higher value point. This is what is meant by increasing prosperity. Prosperity in other words means an increase in the standard of living or quality of life (quality of life). So, prosperity is one thing that all economic actors aim for. The general step taken by the state in realizing its goals is to maintain the rate of economic growth by facilitating community economic activities that encourage an increase in national income. The role of the government is to regulate state revenues and expenditures, which will have a direct or indirect effect on people's production and consumption patterns. Programs are also disbursed in the form of subsidies, empowering the people's economy, as well as maintaining price stability, complementing state support for large industries in order to increase national income.

The main target of the economy is the welfare of the community. The measures chosen should be based on efforts to stabilize economic growth, namely by increasing national income, stabilizing prices (through controlling inflation), and avoiding the growth of unemployment. Prawoto (2009) considered that most government programs for poverty eradication were not very successful because there were deviations in the 
implementation of the plan, in addition to focusing on economic aspects compared to social, cultural, legal, and even religious aspects.

Table 1. The number of poor people in Indonesia and the poverty line used

\begin{tabular}{lllllllll}
\hline Year & \multicolumn{3}{c}{$\begin{array}{c}\text { Number of poor people } \\
\text { (in million) }\end{array}$} & \multicolumn{2}{c}{$\begin{array}{c}\text { Number of poor people } \\
\text { (in percentage) }\end{array}$} & \multicolumn{2}{c}{$\begin{array}{c}\text { Poverty line used } \\
\text { (Rp/capita/moon) }\end{array}$} \\
& Cities & country & All & Cities & country & All & Cities & Country \\
\hline 2011 & 10,95 & 18,94 & 29,89 & 9,09 & 15,59 & 12,36 & 263.594 & 223.181 \\
2012 & 10,51 & 18,09 & 28,59 & 8,6 & 14,7 & 11,66 & 277.382 & 240.441 \\
2013 & 10,63 & 17,92 & 28,55 & 8,52 & 14,42 & 11,47 & 308.826 & 275.779 \\
2014 & 10,36 & 17,37 & 27,73 & 8,16 & 13,76 & 10,96 & 326.853 & 296.681 \\
2015 & 10,62 & 17,89 & 28,51 & 8,22 & 14,09 & 11,13 & 356.378 & 333.034 \\
2016 & 10,49 & 17,28 & 27,76 & 7,73 & 13,96 & 10,7 & 372.114 & 350.420 \\
2017 & 10,27 & 16,31 & 26,58 & 7,26 & 13,47 & 10,12 & 400.995 & 370.910 \\
\hline Averages & $\mathbf{1 0 , 5 5}$ & $\mathbf{1 7 , 6 9}$ & $\mathbf{2 8 , 2 3}$ & $\mathbf{8 , 2 3}$ & $\mathbf{1 4 , 2 8}$ & $\mathbf{1 1 , 2 0}$ & & \\
\hline
\end{tabular}

Source: BPS

There are four general models used to solve the problem of poverty, namely: (1) economic growth, (2) development of an entrepreneurial spirit, (3) providing subsidies, (4) building price stability. These four things are favored in solving the problem of poverty. Economic growth is considered a patent medicine that is at the core of poverty alleviation. Economic growth will open up greater opportunities for the poor to develop their assets. Economic growth refers to the availability of goods and services, both in terms of quantity and quality, as well as increasing living standards. This economic growth must go hand in hand with a fair and balanced distribution of income, in this case preventing economic disparities in the community.

The second point of view is that part of poverty is caused by limited assets, namely work (labor). This situation can be achieved if there is a condition of full employment (full employment), which is a condition where it is easy to get a job so that there is only temporary unemployment. The availability of employment opportunities necessitates the growth of an entrepreneurial spirit, thereby reducing dependence on large companies.

The third thing that is proposed to solve poverty is the provision of subsidies. The pros and cons of this program are rolling. On the one hand, the people are considered to need protection and to move the economic sector at the grassroots, on the other hand, this program adds to the deficit in the state's financial balance. Poverty is not resolved on the grounds that subsidies are not well-targeted.

Another perspective is price stability. It is the poor who are most affected by rising prices, especially prices for basic necessities. They limited assets they have cause not all needs are met. Controlling the inflation rate is expected to save the poor. An indicator of a low level of inflation is that prices are relatively stable, i.e. prices move up slowly over a period of one or two years.

The four solution classifications have been implemented simultaneously. The result can be seen together, poverty still persists. Partial solutions, such as increasing national income, developing MSMEs, providing subsidies, need to be reviewed. Therefore, a new perspective is needed, so that the problem of poverty can be completely resolved. 
The application of the Capitalist-Liberal Political System and SocialismCommunism has proved to be a failure in solving the problem of poverty. Even the application of this system creates structural poverty in the community. A different reality from the application of the Islamic Political Economy system, in which the State guarantees the fulfillment of the basic needs of each person as a whole, as well as the possibility of himself fulfilling his secondary and tertiary needs, according to the level of ability as an individual who lives in a society that has a lifestyle. Guarantee the fulfillment of primary needs (clothing, food, shelter, education, health, and security) is carried out through various mechanisms, either directly or indirectly (Hidayat, 2019).

\subsection{Main Thoughts of Abdurrahman al Maliki}

The Islamic Political Economy, which was initiated by Abdurrahman al-Maliki, is a development of the concept of political economy outlined by an-Nabhani. AnNabhani (1990) defines Islamic economic politics as guaranteeing the satisfaction of all basic (primary) needs of each individual and fulfilling complementary (secondary and tertiary) needs according to their level of ability as individuals living in certain societies, who have a Islamic lifestyle.

Abdurrahman al-Maliki (2000) views that there are important things that must be done by the state, namely the necessity for Islamic countries to design their own economic policies based on the comprehensive thinking they adhere to, namely the Islamic Aqedah. The economic policies of Islamic countries must be in the form of shari'a laws extracted from the Qur'an and as-Sunnah, or the arguments indicated by the two main arguments so that all economic activities that violate the shari'ah must be closed tightly. by the state.

This economic policy will determine the priority scale of state spending. This is because economic policies that are not based on sharia law are corrupt policies, where the results only lead to increasing economic problems, people getting poorer and underdeveloped, and economic pressures getting heavier. Political Economy is the target of laws that deal with the regulation of human cases. The political economy of Islam is not only about increasing the standard of living in a country or the realization of social justice.

The Islamic political economy does not make the growth of national income as its basis, nor does it increase the number of goods and services that guarantee the realization of the prosperity of human life, then free them to obtain them according to their abilities by providing freedom to own and work. This is the basic difference between the political economy of Islam and the political economy of Capitalism. Based on the above, Islam views human needs as divided into two, namely basic needs and complementary needs, while in the capitalist system they are divided into three, namely primary needs. secondary, and tertiary. Islamic economic politics aims to ensure the distribution of state wealth to all individual citizens one by one, so as to ensure the fulfillment of the primary needs of each citizen as a whole, and to ensure that each individual fulfills his complementary needs according to their respective abilities.

The first political economy, related to the fulfillment of basic needs, must be followed by guaranteeing the fulfillment of communal needs by the state at the maximum level that can be provided by the state, which includes aspects of (1) education, (2) health, and (3) security for all people, regardless of economic strata. The three guarantees allow the family's assets to be accumulated and can be utilized by the family, whether consumed or produced. Both are equal in value to the economic cycle in society. The focus of state financial management is to look at 
the things that are important, prioritize them, and then jump to a higher level of prosperity.

This is the foundation of the second Islamic political economy. The second political economy is that the state must open up opportunities for all citizens to open businesses or work. Regarding the business fields opened, it refers to four main economic sources: (1) agriculture, (2) trade, (3) industry, and (4) human resources. The state will open up opportunities for every citizen to work or open a business in agriculture and trade because both do not require high skills.

The state will make industrial policies, in order to be able to achieve high technology quickly. Because it is the industry that will accelerate towards developed countries. A large portion of the state's finances is to build heavy industry, especially industries that produce machine-building machines. Through this, industrialization can take place more efficiently, because it utilizes domestic products. Imports are only for building industrial machinery or materials to support the process. There are no imports for all industrial products. This is the activity of the first stage of building the industry.

The state then built heavy industries using industrial products in the first stage of the industrialization process. These heavy industries are used to meet the strategic needs of the state and society. The state will provide business opportunities for the community to be involved in the industrialization process. The civilian, in this case, is to open up industries that support strategic industry need. The industrialization process requires the support of human resources.

The state must direct its education policy to meet the needs of industry. The state political economy must be in line with the politics of education. The development of the strategic industrial is directed to meet the needs of the state and community. The others purpose are accelerating the economic cycle and opening foreign markets. These conditions resulted in an increase in the standard of living of the community as a whole. This economic power is a prerequisite for solving the problem of poverty.

\subsection{The Foundation for Solving Poverty Problems According to Abdurrahman al-Maliki}

Islam distinguishes two things, namely "Miskin" and "Fakir". Poverty is a condition in which individuals are unable to meet their basic needs, while poverty is a condition in which individuals are unable to meet their needs relative to society. It is this poverty that must be eliminated, while poverty is a condition that cannot be avoided because the condition is relative to the standard of living of the people who continue to develop.

The causes of poverty are generally divided into four, namely: (1) having physical or mental limitations, (2) inadequate competence (intellectual and mental), (3) weak support and resources, and (4) isolated conditions. Physical limitations can occur because they have become old, are chronically ill so they are unable to work, or their organs are not perfect, either from birth or due to various other causes. Mental limitations due to his inhibited thinking ability and fall into this category are insane. This condition will definitely result in poverty if there is no backup from other parties.

Sometimes poverty arises due to inadequate competence so that they are unable to access decent work. Increasing competence is certainly a priority for the state, but the intellectual level of individuals is different, so of course, not all of them can be improved. The politics of education is directed at increasing the productivity of all members of society according to their conditions. The most common thing is that there is a lack of resources and weak support, so they are unable to work or create jobs, and even if they are able to work or create jobs, their income is still limited due to the weak purchasing power of the people. 
The fourth condition, generally accompanied by one of three things that cause poverty, is sometimes absolute because it is isolated. Isolated conditions create additional costs to access them, so prices become more expensive. This condition causes the assets owned to be difficult to develop. This is a condition that makes it seem as if poverty is inherent in human life. It is recognized that poverty is a complex process because it includes many dimensions and overlaps with one another.

Poverty is a multidimensional problem whose handling is not only related to the agenda or economic policy but also to the social, political, and cultural policy agenda. Understanding the economic problems of poor families alone is not enough to make effective poverty reduction policies. However, economic problems remain at the heart of the poverty problem. In economic policy, macroeconomics is fundamental. So an understanding of the interrelationships between macroeconomic policies is the key to formulating anti-poverty policies.

It has also been proven that the emphasis on the consumption gap dimension alone (only on monetary issues) is not enough to answer the problem of poverty, including freeing the population from the poverty trap. However, the economic dimension remains at the core of poverty. Solving other dimensions of poverty without solving economic problems is not solving anything.

In short, the economic problem is a necessary but not sufficient condition to tackle poverty. Opportunities for poor families can be closed if their access to productive resources is hampered and the market is often blocked. An effective government function should be able to remove these barriers and at the same time fixed market mechanisms to work for the benefit of the poor.

The various causes of poverty make the solution cannot be generalized, even though there are main things that are done. Four approaches need to be carried out simultaneously: (1) encouragement to be productive, (2) protection at the family level, (3) protection from the community (through zakat, sadaqah), and (4) state protection. This is the state policy to solve the problem of poverty. This is what is meant by Islamic economic politics to eradicate poverty.

Solutions to meet the needs of human life have been regulated in Islam. Every man has to work. Each man is responsible for his own needs and takes care of his family. If there is a shortage, then the family is responsible for fulfilling it. If it is still not fulfilled, then the responsibility shifts to the community and the state. The state, in this case, used zakat and grants, collecting the tax, and borrowing money or goods to protect people.

This is the pillar to overcome poverty. Certain people get gifts in the form of weaknesses in physically or mentally, or to those who are being sick. Parties who, if they are in economic competition, will be excluded or are being excluded. These zakat and grants are given to the person after the obligation to work and family protection. This guarantee of basic needs will create economic equality at all levels of society.

Compensation (social benefits) given to underprivileged communities will provide many benefits, including moving the wheels of the economy in all sectors of life by increasing people's purchasing power, peace for all levels of society so that it creates positive attitudes and suppresses negative behaviors. People are also encouraged to work so that with guaranteed basic needs, the results can be allocated to other productive sectors, which are expected to eventually raise them to a higher level of prosperity. A weak society will become weaker if it meets health problems. Family wealth can be depleted without a trace when a family member gets a disaster. Guaranteed health services by the authorities will result in an attitude of uniting the people with the authorities. This is the secret of the strength of a country, in addition 
to not dragging back the power of a family to be trapped again in a low level of prosperity (below the poverty line).

In essence, state policies must focus on providing comprehensive protection for the poor, regardless of other aspects. Without this policy, poverty always arises. This comprehensive protection lifts all individuals out of poverty, and into the category of poverty. Individuals who fall into the poor category are very vulnerable to falling into poverty, both when there is an economic shock, or when various things happen, both personal and befalling society in general. It's just that, with comprehensive protection, then all individuals will live this life peacefully. The increase in the purchasing power of the lower class society has caused the economic activity at the grassroots level to strengthen and turn the wheels of the economy. This approach is 180 degrees different from the efforts made by governments in various countries, which prioritize the protection of large industries to boost national income.

The leap to achieve a higher level of economic prosperity cannot be separated from his intellectual abilities, for that there must be a guarantee from the state to all its people to improve its quality, through education. Giving this equal opportunity will open up opportunities for weak parties to be able to escape from the abyss of poverty which can be hereditary. Guaranteed quality but free education will produce superior human resources, something that is highly expected by the state.

The existence of health and security guarantees will increase the productivity of the people, along with the development of their intellectual abilities. The acceleration of the economic cycle at the bottom level that comes from comprehensive protection will simultaneously increase the welfare of the people. Stimulus is what will launch the rotation of the engine of the economy. It's just that it should be noted that all economic resources must remain on the normal path, so it must be accompanied by closing the doors of immorality. Without closing the door to immorality, the community's economic cycle will be disrupted.

This is the typical style of the Islamic political economy. Ease of working/business is opened as wide as possible by the government. Establishment of a business without the need for a permit first. The government through third parties (associations) will set certain standards for products and services, to ensure product quality and brand safety for each industry. Companies both at the micro, small, medium, and large levels do not need to pursue purely economic aspects, thus sacrificing quality. The company is also not burdened with the minimum wage standard, which causes production prices to be high, due to comprehensive protection from the state until the industry reaches its level of efficiency so that wages can be equal to the work done.

Another problem that arises is the concept of a regional Minimum Wage (UMR). Even though the UMR is used to protect workers from oppression by employers, it also slows down the growth of the business world. Meeting the needs of workers is borne by the employer. The problem is that not all economic activities have the same value, so they can be equated with the necessities of life. It should be adjusted to the activity and the pleasure of both parties. Does not burden employers but does not oppress workers. The existence of the UMR burden will make it difficult for "UMKM" to grow. The slow growth of "UMKM" will create a row of unemployment. The unemployment ranks weaken the market's ability to absorb industrial products (including agriculture, animal husbandry, fisheries). This will have an impact on the service industry.

The state, to ensure the welfare of the people as a whole, must create a special economic mechanism that is not allowed to set prices. Prices are made to float according to market conditions, namely the supply of goods and services and 
demand. This floating price makes the flow of goods and services to where they should be, following price conditions. High prices will make the supply increase so that the availability of goods and services is guaranteed. Even so, the state must establish a stable standard for the medium of exchange.

The currency is based on gold and silver, which has been abandoned since 1971 . Massive inflation occurred due to the development of fiat money, whose value always decreases with time. This condition will hit the lower class society because the production is low tech, where supply and demand are relatively stable. The state guarantee for a stable medium of exchange will serve two purposes, namely protecting the lower class and ensuring a stable economic cycle. The solution to the problem of poverty that has been implemented so far is considered to be a responsibility so that it seems that it maintains poverty, not alleviates poverty.

The full dedication of the system to providing comprehensive protection to all individuals who become citizens is the only logical solution to alleviating poverty. This is the duty of the individual, the family, society, and the state. The government must monitor that there are no more poor people, with monitoring at a smallest regional level (RT).

The state then opens up business opportunities as wide as possible, so that the level of community productivity increases, and offsets the increase in the purchasing power of the lower level people because of the comprehensive guarantee of their basic needs. Even though "UMKM" have contributed to creating jobs and enabling people to survive in meeting their needs, they will not be able to solve the problem of poverty as long as the economic policies implemented by the government are still capitalistic.

Based on this, the problem faced is not with "UMKM" themselves, but related to the environment that surrounds them. Because "UMKM" are also in the trap of the economic vortex of large companies. This is where the state should be present. It's just that with the grip of the current secular-capitalist system, it is very difficult for economically weak parties (UMKM) to escape from economic problems, poverty, and economic inequality unless the business climate changes to become Islamic. The country's strategic step to solving the problem of poverty is to focus on building a strong industry. In other words, carry out the industrial revolution.

Meanwhile, the community is allowed to develop the business world, both "UMKM" and large businesses, with the right economic interactions. The role of the community in opening a business can be in the form of an individual business or a company. Individual businesses may or may not involve workers. Companies that are built must follow Shari'ah, so they can choose one of several forms, such as syirkah inan, syirkah abdan, syirkah mudlarabah, syirkah wujuh, and syirkah mufawadlah. Within the company, it can employ one or more workers or not, according to the size of the business being built. This is in addition to being protected from poverty, it will also roll out the economy in the lower classes so that there are "UMKM".

\section{CONCLUSION}

Abdurrahman al-Maliki's thoughts deserve to be considered in efforts to eradicate poverty as a whole, through comprehensive backup efforts for every individual who experiences poverty, either by family, community, or state. This economic policy guarantees that poverty can be eliminated absolutely. This condition needs to be supported by education politics and full health and security guarantees by the state for all citizens regardless of their level of welfare. The state must close all doors of immorality so that there is an acceleration of the economic cycle because it is in a lawful and reasonable (not speculative) path. On the other hand, the state must focus 
on developing the industrial sector so that the level of prosperity can increase, complementing the growth of the agricultural and trade sectors.

The political economy of Islam which was initiated by Abdurrahman al-Maliki is theoretically able to guarantee an increase in people's living standards and can provide directions for the formation of human civilization.

This research is still limited to the general concept developed by Abdurrahman al-Maliki. Further elaboration is needed regarding the concept of guaranteeing basic needs for each citizen, as well as how the country's economic development pattern is to become a developed country.

\section{Refereces}

Aprianto, N.E.K. (2017). Kemiskinan dalam Perspektif Ekonomi Politik Islam. Islamiconomic: Jurnal Ekonomi Islam, 8(2), 169-188.

DOI: $10.32678 /$ ijei.v8i2.60

Hidayat. (2019). Politik Ekonomi Dan Kemiskinan (Studi Komparatif Politik Ekonomi Kapitalis, Sosialis, Dan Islam). Jurnal Wedana, 5(2), 598-609.

Ikhsan, M. (2010). Kebijakan Ekonomi Makro, Khususnya stabilisasi harga dan penanggulangan kemiskinan, Lembaga Penerbit, Jakarta.

Ilmi, S. (2017). Konsep Pengentasan Kemiskinan perspektif Islam. Al-Maslahah, 13(1), 67-84. DOI: https://doi.org/10.24260/almaslahah.v13i1.918

Maliki, A. (2001). Politik Ekonomi Islam. Terjemahan oleh Ibnu Sholah, dari AsSiyasatu al-Iqtishadiyatu al-Mutsla. Bangil: Al-Izzah.

Papilaya, J. (2020). Kebijakan Publik Dalam Pengentasan Kemiskinan (Suatu Kajian Peranan Pemerintah Dalam Pengentasan Kemiskinan). Jurnal Bimbingan dan Konseling Terapan, 4(1), 77-91.

DOI: http://dx.doi.org/10.30598/jbkt.v4i1.1113

Prawoto, N. (2009). Memahami Kemiskinan dan Strategi Penanggulangannya. Jurnal Ekonomi dan Studi Pembangunan, 9(1), 56-68.

Sugandi, YS. (2016). Program Penanggulangan Kemiskinan Perkotaan: Pengalaman Kota Bandung. Jurnal Analisis dan Pelayanan Publik, 2(1), 109-127.

DOI: https://doi.org/10.31947/jakpp.v2i1.1525

Sugiyono. (2017). Metode Penelitian Kuantitatif, Kualitatif, dan R\&D. Alfabeta, Bandung.

https://www.bps.go.id/statictable/2014/01/30/1494/jumlah-penduduk-miskinpersentase-penduduk-miskin-dan-garis-kemiskinan-1970-2017.html accessed 19 Oktober 2021. 